\title{
Aikuiskasvatus on tulevaisuudessa avoin koko historialtaan
}

38 VUOTTA. 152 NUMEROA. I2 800 SIVUA. Siinä lukuja, jotka ovat Esko Clarke Sarion työmaata lähikuukausina.

Kansanvalistusseura digitoi Suomen tiedekustantajien liiton apurahalla Aikuiskasvatuksen vanhat numerot. Clarke Sario on palkattu tehtävään konsultiksi.

Hän tutkailee urakkaansa innostuneena.

"Tiedelehden vuosikertoihin perehtyminen on tutkimusmatka siihen, mitkä asiat milloin ovat tutkijoita kiinnostaneet. Digitoitu aineisto myös tarjoaa aivan uusia mahdollisuuksia tutkia sisältöä."

Tulevaisuudessa Aikuiskasvatus on kaikkien vapaasti luettavissa koko ilmestymisajaltaan, vuodesta 1981 lähtien. Tiedelehden digitointi on monivaiheinen prosessi: on määritettävä metatiedot, selvitettävä kirjoittajien lupia, asiasanoitettava kirjoitukset.

"Tietotekniikka ja sen käytettävyys täyttivät päiväni aiemmassa työssäni, joten tiedostomuotojen miettiminen on tuttua. Eniten on hyötyä varmasti informatiikan ja kirjastojen sisällönkuvailun kokemuksesta”, Clarke Sario arvioi.

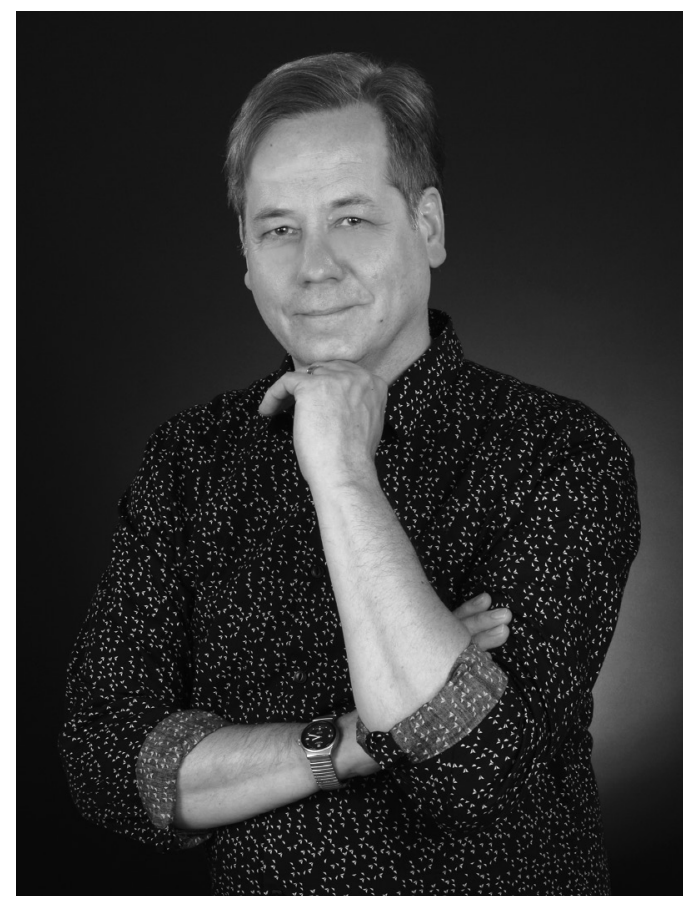

Konsultti Esko Clarke Sario vie tiedelehden vanhat numerot digiaikaan.

\section{Allekirjoita digitointilupa}

Jos olet kirjoittanut Aikuiskasvatus-tiedelehteen ennen vuotta 2019, allekirjoita verkossa lupa digitoida kirjoituksesi. Samalla voit antaa asiasanat tekstiisi: bit.ly/aikuiskasvatuksen_digitointilupa 